\title{
Hyaluronan Elevates Cell Cycle Regulators P130, E2F4, and P27kip1 in Dormant Human Mesenchymal Stem Cells to Regulate Cell Quiescence
}

\author{
Meei-Ru Lin ${ }^{1 *}$, Tzyy Yue Wong', Chun-Hsien Wu' and Lynn LH Huang ${ }^{1-4}$ \\ ${ }^{1}$ Institute of Biotechnology, College of Bioscience and Biotechnology, National Cheng Kung University, Taiwan \\ ${ }^{2}$ Research Center of Excellence in Regenerative Medicine, National Cheng Kung University, Tainan, Taiwan \\ 3Institute of Clinical Medicine, College of Medicine, National Cheng Kung University, Tainan, Taiwan \\ ${ }^{4}$ Advanced Optoelectronic Technology Center, National Cheng Kung University, Tainan, Taiwan
}

\begin{abstract}
Quiescence conserves the properties of stem cells whilst they are dormant. The mechanisms associated with dormancy involve various cell regulators. Here, the effects of hyaluronan (HA; a polysaccharide associated with the extracellular matrix), on the mesenchymal stem cell cycle and the involvement of p130 and E2F family proteins in mesenchymal stem cell cycle regulation, were evaluated. Placenta-derived mesenchymal stem cells (PDMSCs) were cultured on either a normal tissue culture surface (TCS) or a surface coated with HA. Cell population percentages at the $\mathrm{G} 0 / \mathrm{G} 1, \mathrm{~S}$, and $\mathrm{G} 2 / \mathrm{M}$ phases were analyzed $36,40,44,48$, and $50 \mathrm{~h}$ post-seeding using flow cytometry. At $36 \mathrm{~h}$, HA-treated cells had more PDMSCs in the G0/G1 phase (61.59\% versus $43.61 \%$ in the TCS group). At and 48 and 50 $\mathrm{h}$ for the HA and TCS groups, respectively, PDMSCs had highly similar population distributions in cell cycle phases; thus, these cells were used to study cell cycle regulators. Pocket proteins ( $p 130, p 107$, and pRb), E2F family proteins (E2F3, E2F4, and E2F5), using sand the binding of p130 to E2F4 and DP1 were analyzed with western blots and coimmunoprecipitation. The HA group at $48 \mathrm{~h}$ exhibited increased $\mathrm{p} 130$ and E2F4 protein expression compared with the TCS group at $50 \mathrm{~h}$ (4.3-fold and 1.5-fold, respectively), and the binding of p130 to E2F4 and DP1 was detected 36, 48 , and $50 \mathrm{~h}$ post-seeding. In this studyHence, a the HA-regulated formation of a p130/E2F4 complex was observed in PDMSCs, which provides to suggests that the mesenchymal stem cell cycle is regulated by HA as an extracellular matrix.
\end{abstract}

Keywords: E2F; Extracellular matrix; Hyaluronan; Mesenchymal stem cells; Retinoblastoma family proteins

Abbreviations: CDK: Cyclin-dependent Kinases; ECM: Extracellular Matrix; HA: Hyaluronan; PDMSC: Placenta-derived Mesenchymal Stem Cell; RB: Retinoblastoma; shRNA: Short Hairpin RNA; TCS: Tissue Culture Surface

\section{Introduction}

Stem cells possess the capacity for self-renewal, differentiation, and to act as precursors for somatic cells [1]. In humans, stem cells can be classified as embryonic or adult, which are further classified into specific types such as hematopoietic, mesenchymal, neural, limbal, intestinal, and hair follicle stem cells. Most adult stem cells are multipotent $[2,3]$. In vivo, stem cells are preserved in a dormant or quiescent state for long periods until they are required for further cell differentiation [4]. Because of their favorable properties, which include self-renewal and a lack of immune responsiveness, stem cells are a major source for cellbased tissue engineering and regenerative medicine [5].

Stem cells reside in the microenvironment known as the stem cell niche, which provides stem cell growth factors, extracellular matrices (ECMs), and niche cells for structural support and signaling transmission [6,7]. Hyaluronan (HA) is a major component of both the hematopoietic and mesenchymal stem cell niche, and is widely distributed in the connective, epithelial, and neural tissues [8]. HA is produced by hyaluronan synthase genes (HAS1, HAS2, and HAS3) [9-11]. HA have a linear conformation with non-sulfated glycosaminoglycans composed of D-glucuronic acid (1- $\beta-3)$ and $\mathrm{N}$-Acetyl-D-glucosamine (1- $\beta-4)$ repeats $[12,13]$. HAS genes produce HAs with various molecular weights during development and extrinsic stimuli [10] and HAs are classified into 15 types according to the number of these repeats [14]. Furthermore, it regulates intracellular signal transduction via its receptor CD44 and Receptor for HA-
Mediated Motility (RHAMM) [15,16]. HA has been shown to support and protect cells from damage, stress and oxidants and influence cell proliferation, differentiation, and migration $[17,18]$. Despite the apparent importance of HA, its influence on the cell cycle regulation of stem cells dormancy maintaining has not been comprehensively studied. In vivo, stem cells can be awakened from the G0 phase to enter cell cycle progression [4]. Our previous studies indicated that HA had the potential to prevent cellular senescence (an irreversible cell cycle arrest), to maintain stem cell differentiation potentials in murine adipose-derived stromal cells, and to hold mesenchymal stem cells in a reversible cell cycle arrested mode [19,20]. It was shown that the retinoblastoma (RB) family proteins, also known as pocket proteins ( $\mathrm{pRb}, \mathrm{p} 107$, and $\mathrm{p} 130$ ), regulated cell cycle exit and entry [21]. During cell cycle arrest, RB proteins may bind to E2F members to repress transcription of genes [22], including DNA replicationrelated genes for $\mathrm{G} 1$ progression to $S$ phase [23]. There are eight types of $E 2 F$ genes that give rise to 10 distinct $\mathrm{E} 2 \mathrm{~F}$ proteins, and each E2F member targetstospecific pocket protein [24]. In general, un-phosphorylated RB family members bind to E2F to repress E2Fassociated gene transcription and produce cell cycle arrest [24,25]. Conversely, phosphorylated RB members dissociate from $E 2 F$, leading

*Corresponding author: Meei-Ru Lin, Institute of Biotechnology, College of Bioscience and Biotechnology, National Cheng Kung University, Taiwan, Tel: +8867-3450359; Fax: +886-06-2080165; E-mail: meeiyen@gmail.com

Received June 06, 2016; Accepted June 23, 2016; Published June 27, 2016

Citation: Lin MR, Wong TY, Wu CH, Huang LLH (2016) Hyaluronan Elevates Cell Cycle Regulators P130, E2F4, and P27 kip1 in Dormant Human Mesenchymal Stem Cells to Regulate Cell Quiescence. J Stem Cell Res Ther 6: 345. doi:10.4172/2157 7633.1000345

Copyright: (c) 2016 Lin MR, et al. This is an open-access article distributed under the terms of the Creative Commons Attribution License, which permits unrestricted use, distribution, and reproduction in any medium, provided the original author and source are credited. 
to $E 2 F$-related gene transcription and G1/S cell cycle progression [26]. The E2F members E2F1,E2F2, and E2F3 are known to form complexes with heterodimer proteins (DP1 or DP2) and exclusively with pRb, and they repress gene transcription and cause cell cycle arrest $[27,28]$. During the G0 phase, two other E2F members, E2F4 and E2F5, bind preferentially to $130 / \mathrm{DP} 1$ and $\mathrm{p} 107 / \mathrm{DP} 1$, respectively, to repress gene transcription. E2F6, E2F7, and E2F8 also form a complex with DP1; however, they function independently of pocket proteins in regulating cell cycle arrest $[23,29]$. E2F-repressed cell cycle genes include those that encode cyclin-dependent kinases (CDKs) and cyclins. The E2F/RB complex may be disrupted in the presence of mitogenic stimuli, which leads to the phosphorylation of RB, activation of CDKs and cyclins, and progression of the cell cycle [30]. CDK4/6 has been shown to interact with cyclin $\mathrm{D}$ to initiate $\mathrm{RB}$ phosphorylation and G1/S transition $[30,31]$. Furthermore, CDK2 interacts with cyclin $\mathrm{E}$ to promote $\mathrm{S}$ phase entry [32]. Recently, the possible role of E2F was extended by reports of an association with stem cell fate [26,33]. The role of the E2F/RB complex in progenitor cells is well-studied, and the ECM is known to be important for stem cell maintenance in vivo; however, the influence of $\mathrm{HA}$ as an ECM on E2F/RB has not yet been clarified.

In this study, the E2F4/RB2/DP1 complex was analyzed in placenta-derived mesenchymal stem cells (PDMSCs) cultured in the presence of HA. We found that PDMSCs cultured in the presence of HA had a higher cell population in the G0/G1 phase compared with PDMSCs cultured on a normal tissue culture surface (TCS). Where the population distribution of cell cycle phases was similar, PDMSCs cultured on a HA-coated surface exhibited increased expression of p130, E2F4, and E2F5 proteins compared to with PDMSCs cultured on a normal TCS; furthermore, p130 protein was coupled with E2F4 and DP1.

\section{Methods and Materials}

\section{Isolation and cultivation of PDMSCs}

PDMSCs were obtained from human placentas of mothers who donated to our study at the National Cheng Kung University Hospital. Handling of the full-term placentas was approved by the Institutional Review Board. After removing the amnion and decidua, the chorionic villi were minced, washed in Hank's balanced salt solution (SigmaAldrich), and then digested with $200 \mathrm{U} / \mathrm{ml}$ of type II collagenase (Worthington Biochemical Corp.) in a water bath $\left(37^{\circ} \mathrm{C}\right)$ with orbital shaking $(100 \mathrm{rpm})$ for $30 \mathrm{~min}$. The tissue mixture was sieved sequentially through 500- to 104- to 37- $\mu \mathrm{m}$ mesh to remove undigested fragments. Mononuclear cells were isolated by mixing with $1.073 \mathrm{~g} / \mathrm{cm}^{3}$ Percoll (GE Healthcare), and subsequently centrifuged at $900 \times g$ for $30 \mathrm{~min}$ at $4^{\circ} \mathrm{C}$. They were seeded at a density of $3 \times 10^{4}$ cells $/ \mathrm{cm}^{2}$ in Dulbecco's modified Eagle's medium-low glucose (Gibco) supplemented with $10 \%$ fetal bovine serum (Gibco) and $100 \mathrm{U} / \mathrm{ml}$ gentamycin, and then incubated at $37^{\circ} \mathrm{C}$ in $5 \% \mathrm{CO}_{2}$. After $10-14 \mathrm{~d}$, colonies of PDMSCs were trypsinized and sub-cultured for expansion on a polystyrene TCS. For treatment with HA, PDMSCs were cultured on a HA-coated surface at P5 (otherwise indicated as $\mathrm{P} 4+1$ throughout the article). Cells in the following experiments were all assessed at P5.

\section{Preparation of the HA-coated surface}

HA solution was prepared by dissolving HA powder ( $\mathrm{MW}=1470$ $\mathrm{kDa}$; Lifecore) in $\mathrm{ddH}_{2} \mathrm{O}$ (the solution was then stored at $4^{\circ} \mathrm{C}$ ). To produce the HA treatment, the TCS was coated with the HA solution $\left(30 \mu \mathrm{g} / \mathrm{cm}^{2}\right)$ and allowed to dry. Subsequently, PDMSCs were seeded at $1 \times 10^{4} \mathrm{cells} / \mathrm{cm}^{2}$ to assess the TCS and HA treatment groups.

\section{Identification of mesenchymal stem cell surface markers}

PDMSCs were harvested at P5 and stained with the following antibodies: CD9, CD13, CD29, CD44, CD45, CD73, and HLA-ABC (BioLegend); CD34, CD90, and CD105 (BD Pharmingen). The cell populations were determined by flow cytometry (FACscan; BD) and displayed as histograms. The results were analyzed using WinMDI2.9 software (Purdue University Cytometry Laboratories).

\section{Cell cycle population distribution percentage analysis}

Harvested PDMSCs were fixed in ice-cold $70 \%$ ethanol at $-20^{\circ} \mathrm{C}$ overnight. After cells were centrifuged at $300 \times g$ and then washed three times with PBS, they were stained with propidium iodide (SigmaAldrich) containing $0.5 \%$ Triton X-100 at room temperature for $1 \mathrm{~h}$ in darkness. They were then washed and re-suspended in PBS for flow cytometric analysis. The percentage of cells in the G0/G1, S, and G2/M phases was analyzed by using ModFit LT software (Verity Software House).

\section{Western blots}

PDMSCs were lysed for $30 \mathrm{~min}$ in lysis buffer with $50 \mathrm{mM}$ Tris $\mathrm{pH}$ 7.5, $150 \mathrm{mM} \mathrm{NaCl}, 0.5 \mathrm{mM}$ EDTA, $1 \%$ Triton X-100, and proteinase inhibitor cocktail (Roche), and then spun down at $12,000 \mathrm{rpm}$ for $20 \mathrm{~min}$. Proteins were separated in 10-12\% gradient SDS-PAGE and transferred to a PVDF membrane. Blocking was performed using $5 \%$ skim milk in TBST (20 mM Tris, $150 \mathrm{mM} \mathrm{NaCl}$, and $0.1 \%$ Tween 20) buffer at room temperature for $1 \mathrm{~h}$. The following specific antibodies were then incubated with the proteins in blocking buffer at $4^{\circ} \mathrm{C}$ overnight: anti-E2F3, anti-E2F4, anti-E2F5, anti-p130, anti-p107, antiRb, anti-DP1 (Santa Cruz Biotechnology); anti-p27 ${ }^{\text {kip1 }}$, anti-p21 $1^{\text {cip1 }}$, anti-p57 ${ }^{\text {kip2 }}$, anti-p-CDK2 ${ }^{\text {Thr160 }}$ (Cell Signaling Technology); and cyclin D2 (Abcam). Unconjugated antibodies were washed away with TBST buffer, proteins were subsequently incubated with secondary antibodies at $4^{\circ} \mathrm{C}$ for $1 \mathrm{~h}$, and then they were washed once more with TBST. After the proteins were reacted with enhanced chemiluminescence solution (Millipore), LAS-4000 (GE Healthcare) was applied to determine protein expression.

\section{Real-time PCR}

Total RNA was extracted by using TRI reagent (Sigma-Aldrich), and the cDNA was synthesized with a reverse transcriptase system (Promega). The following primer pairs were mixed with cDNA and SYBR Green I master mix (Roche), and fluorescence was assessed using real-time PCR (Light Cycler 480; Roche): E2F3 (forward 5'-TTGGGCACTACAGGTAGC-3', reverse 5'-GTAATACACAAGGTGGCGAT-3'); E2F4 (forward 5' $5^{\prime}$-TGGTGAACAAGGAGGCAT-3', reverse 5'-GGAGTGAGCTGAGGACTAT-3'); E2F5 (forward 5' ${ }^{\prime}$-TGATCAGCAGAAGTTGTGGC-3', reverse 5'-TGTTGCTCAGGCAGATTTTG-3'); p130 (forward 5'-TTGGGAATTTAGATGAGCGG-3', reverse 5' - TTAGCAATAGCCTGGGTTGG-3'); p107 (forward 5'-GATCAGCTCCTCCTTTGTGC-3', reverse 5'-AAGGAGAGAGTGGTGGAGCA-3'); and pRb (forward 5'-TGCATGGCTCTCAGATTCAC-3', reverse 5'-CAGACAGAAGGCGTTCACAA-3').

\section{Co-immunoprecipitation}

Protein A sepharose CL-48 (1 g; GE Healthcare) was dissolved in $1 \mathrm{ml}$ PBS containing $0.5 \%$ Triton X-100 and mixed overnight with rotation. After washing three times with PBS, equal amounts of sepharose required for each treatment were incubated with primary 
Citation: Lin MR, Wong TY, Wu CH, Huang LLH (2016) Hyaluronan Elevates Cell Cycle Regulators P130, E2F4, and P27kip in Dormant Human Mesenchymal Stem Cells to Regulate Cell Quiescence. J Stem Cell Res Ther 6: 345. doi:10.4172/2157-7633.1000345

Page 3 of 9

antibodies at $4^{\circ} \mathrm{C}$ for $2 \mathrm{~h}$ with rotation. Following the removal of unconjugated antibodies, protein lysates were added and incubated for $2 \mathrm{~h}$. Finally, the sepharose-lysates mixture was collected using centrifugation at 2,000 rpm for $3 \mathrm{~min}$ and then re-suspended in order to perform western blotting.

\section{Preparation of p27-knockdown PDMSCs}

The short hairpin RNA (shRNA; TRCN0000009857) that interferes with gene transcription of p27 was obtained from the National RNAi Core Facility in Taiwan. The pLKO.1-puro vector that contains the U6 promoter and binds with the p27 shRNA sequence was used to form a lentivirus by co-transfection with pCMV- $\Delta 8.91$ and pMD-G using the calcium phosphate method. The viral medium was collected and subsequently used to infect the PDMSCs for $2 \mathrm{~d}$. The PDMSCs were then selected by using $3 \mu \mathrm{g} / \mathrm{ml}$ of puromycin (MDBio). PDMSCs that survived selection were sub-cultured for expansion and examined for knockdown efficiency using western blotting.

\section{Statistical analysis}

Statistical differences were assessed by Student's t-test. $P<0.05$ was considered statistically significant. Data were expressed as the mean \pm $\operatorname{SEM}(\mathrm{n}=3)$.

\section{Results}

\section{Surface markers were unaffected in the presence of $\mathrm{HA}$}

To confirm the expression of surface markers on PDMSCs, CD9, CD13, CD29, D44, CD73, CD90, CD105, HLA-ABC, CD34 and CD45 were analyzed using flow cytometry. PDMSCs were positive for D9, CD13, CD29, D44, CD73, CD90, CD105, and HLA-ABC in the TCS and HA groups (Figure 1A). Furthermore, PDMSCs were negative for CD34 and CD45 (Figure 1A).

\section{HA maintained PDMSCs in the G0/G1 cell cycle phase}

The population distributions of cell cycle phases were analyzed for

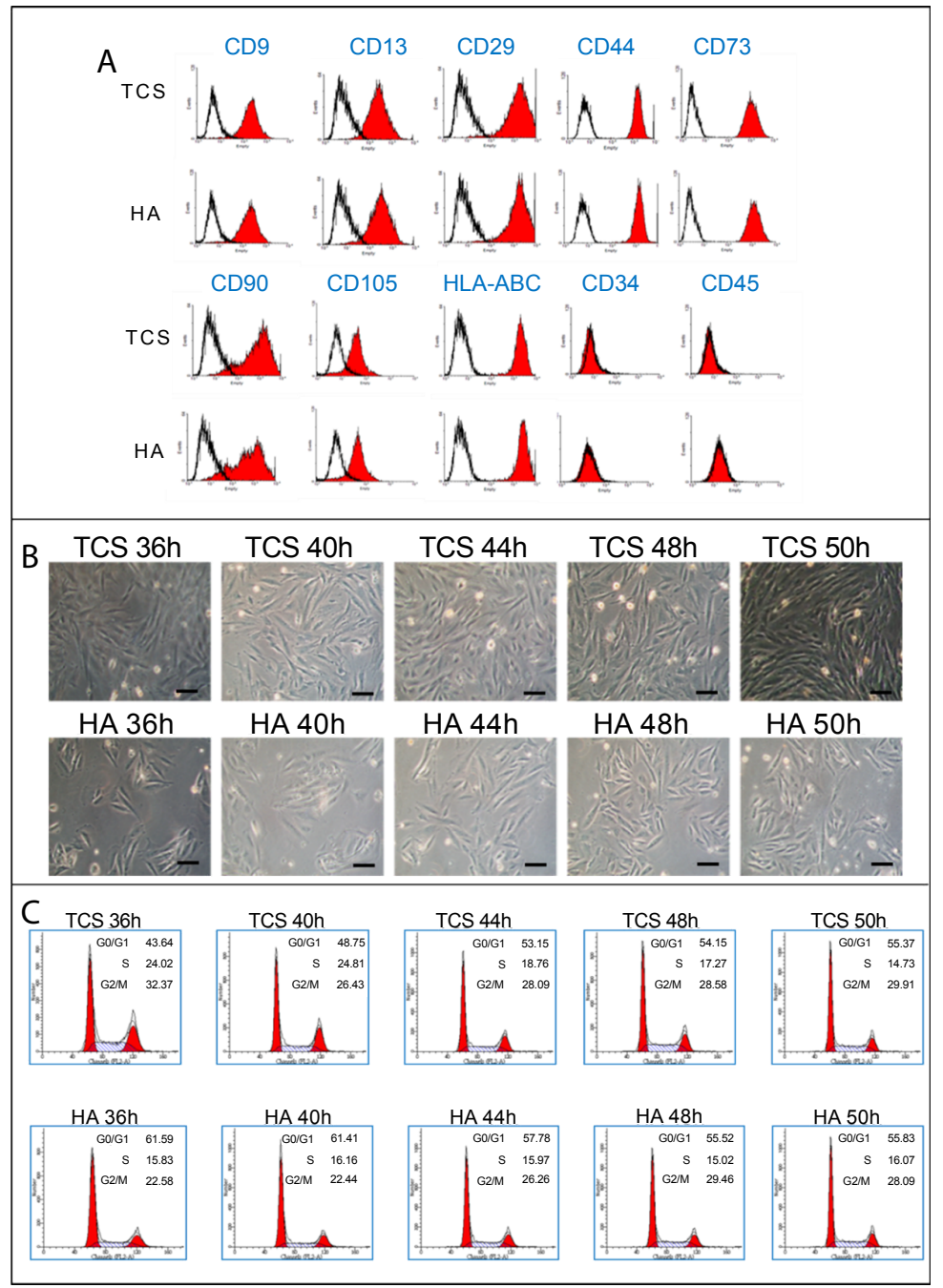

Figure 1: Hyaluronan retained PDMSCs in the G0/G1 phase and maintaining stem cell marker expression. (A) PDMSCs cultured for five passages (P5 for TCS and $\mathrm{P} 4+1$ passage for $\mathrm{HA}$ ) were analyzed for mesenchymal stem cells marker expression at $36,40,44,48$, and $50 \mathrm{~h}$ post-seeding. (B) The PDMSCs were seeded with equal cell density and observed at $36,40,44,48$, and $50 \mathrm{~h}$ post-seeding: cells cultured on TCS had a fibroblastic morphology, whereas HA-treatment caused PDMSCs to cluster together and show different morphology of cells. (C) PDMSCs cell cycle population distribution percentages were analyzed to determine time points with similar cell cycle population distributions. The population distribution percentages of the G0/G1, S, and G2M phases were measured using Mod Fit software. Scale bar $=100 \mu \mathrm{m}$. 
Citation: Lin MR, Wong TY, Wu CH, Huang LLH (2016) Hyaluronan Elevates Cell Cycle Regulators P130, E2F4, and P27kip in Dormant Human Mesenchymal Stem Cells to Regulate Cell Quiescence. J Stem Cell Res Ther 6: 345. doi:10.4172/2157-7633.1000345

Page 4 of 9

PDMSCs to ensure that population distributions were approaching identical. Chemicals for synchronization were omitted to ensure the properties of stem cells were maintained. Hence, for the TCS and HA groups, PDMSCs at P5 and P4+1, respectively, were seeded and harvested at various time points without using synchronization chemicals. PDMSCs in the TCS group presented a fibroblastic-like morphology, whereas PDMSCs in the HA group formed clusters (Figure 1B). At $36 \mathrm{~h}$, the TCS and HA groups had $43.6 \%$ and $61.6 \%$ of cells in the G0/G1 phase, respectively (Figure 1B). The population distribution among cell cycle phases was highly similar for TCS- and HA-based cells at 50 and $48 \mathrm{~h}$ post-cell seeding, respectively (TCS at
50 h: G0/G1 55.37\%, S 14.73\%, and G2/M 29.91\%; HA at 48 h: G0/ G1 55.52\%, S 15.03\%, and G2/M 29.46\%). Based on these similar population distributions, the following experiments were conducted to study the cell cycle regulators (Figure 1C).

\section{HA mediated the elevated expression of E2F4 and p130}

When comparing $50 \mathrm{~h}$ post-seeding for TCS and $48 \mathrm{~h}$ for HA treatments, HA-based treated cells exhibited a 1.5-fold and 4.2fold increase in E2F4 and p130 mRNA expression, respectively, compared with relative expression levels in TCS-based cells (Figure 2A). Additionally, the presence of HA led to increases in protein

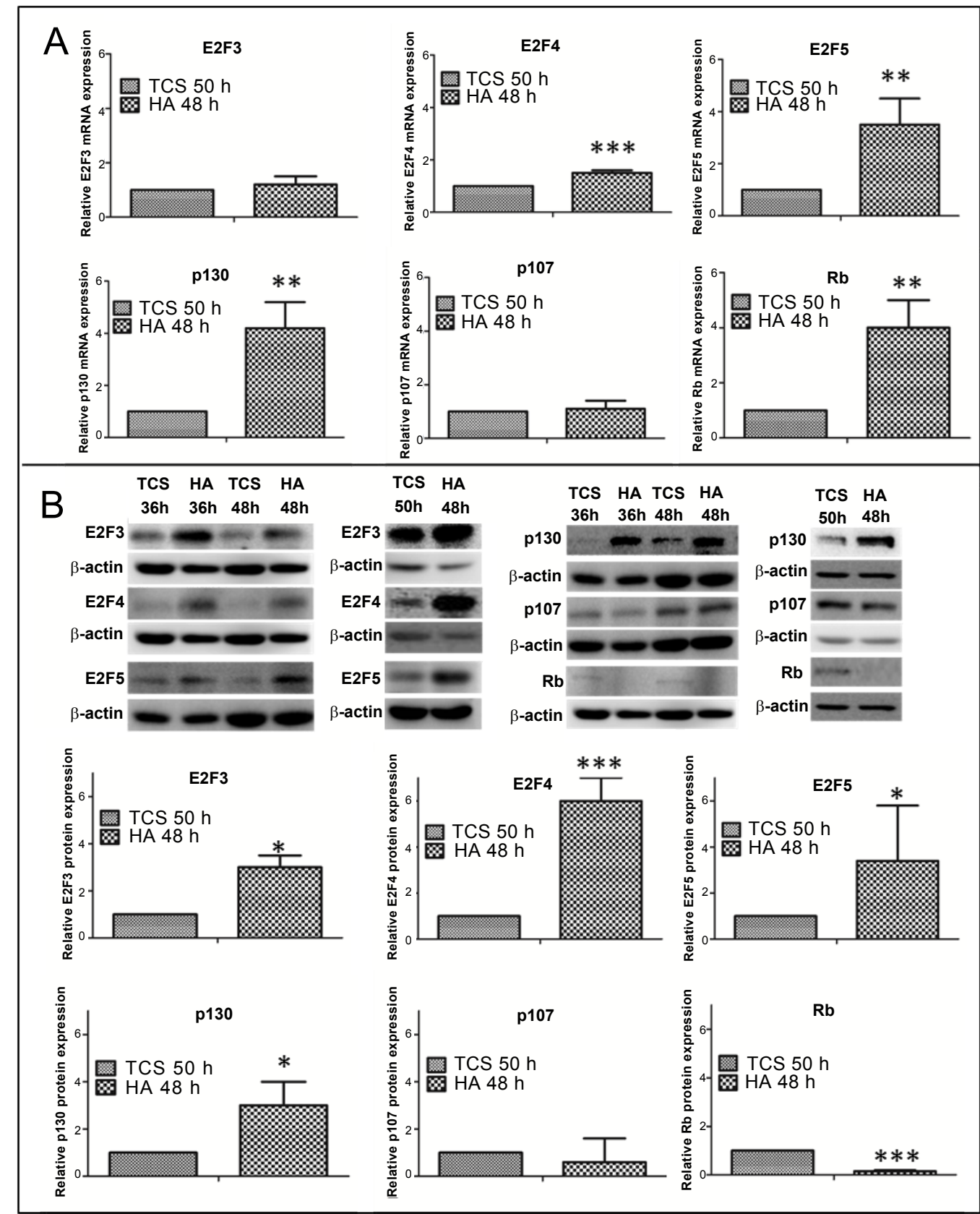

Figure 2: E2F family and p130 protein expression was HA-dependent. (A) The expression of E2F3, E2F4, E2F5, p130, p107, and Rb mRNA was analyzed at 50 $\mathrm{h}$ for TCS-based cells and $48 \mathrm{~h}$ for HA-treated cells. (B) Protein lysates were harvested at 36 , 48, and $50 \mathrm{~h}$ for both TCS and HA groups, and western blotting was conducted to assess E2F3, E2F4, E2F5, p130, p107, and Rb. Data represent the mean \pm SEM from three independent experiments. ${ }^{*} p<0.05$, ${ }^{* *} p<0.01$, ${ }^{* * *} p<0.001$ versus TCS. 
expression as follows: 3-fold increase in E2F3, 6-fold increase in E2F4, 3.4-fold increase in E2F5, and 3-fold increase in p130 compared with the protein expression of TCS-based cells (Figure 2B). The expression of p107 protein did not differ significantly between the HA and TCS groups, whereas $\mathrm{Rb}$ expression was not detected in HA-treated cells (Figure 2B).

\section{Interactions between E2F4, p130 (RB2), and DP1 were HA- dependent}

Co-immunoprecipitation was performed to study the interaction between p130 and E2F4. For co-immunoprecipitation of protein lysates with p130, equal protein amounts were loaded and anti-E2F4 antibody was used to detect any coupling with p130. Results indicated that p130 formed a complex with E2F4 at 36, 48, and $50 \mathrm{~h}$ in the TCS and HA groups (Figure 3A). Likewise, the E2F4/p130 complex was coupled with DP1 (Figure 3B).

\section{Transition to G1/S was blocked in the presence of HA}

In HA-treated cells, the expression of p27kip1 was 2-fold higher and the expression of cyclin D2 was 0.6-fold lower than that relative to expression in TCS-based cells (Figure 4A). The expression of the other $\mathrm{G} 1 / \mathrm{S}$ phase transition regulators, $\mathrm{p} 57^{\mathrm{kip} 1}$ and $\mathrm{p} 21^{\mathrm{cip}}$, did not differ significantly (Figure $4 \mathrm{~A}$ ). Based on these results, p2 $7^{\mathrm{kip} 1}$ was knocked down to observe any changes in the expression of E2F4 and p130. With p $27^{\text {kip } 1}$ knockdown, expression of E2F4 decreased in HA-treated cells. Figure $4 \mathrm{~B}$, but levels of p130 did not decrease relative to those in the TCS group (Figure 4B). Furthermore, p130 up-levels in p2 $7^{\text {kip } 1}$ knockdown cell indicated the compensation effects of p130 to block G1 to $\mathrm{S}$ transition.
The culture conditions to which PDMSCs were exposed, i.e., growth on a TCS or on a surface coated with $30 \mu \mathrm{g} / \mathrm{cm}^{2} \mathrm{HA}$, led to a significant difference in cell growth rate (Figure 5A). The slowing down of cell growth with HA treatment indicated that the cell cycle of PDMSCs was undergoing regulation. Taken all together, our results suggest that HA can be considered as an ECM factor that maintains PDMSCs in a dormant state, confirming by G0 specific via up-regulation of E2F4 and p130 protein expression and p130 dephosphorylation (Figure $5 B)$. Furthermore, the PDMSCs were not released into G1/S phase progression, which is implied by the up-regulation of p27 $7^{\mathrm{kip} 1}$ in HAtreated cells (Figures $4 \mathrm{~A}$ and $5 \mathrm{~B}$ ).

\section{Discussion}

High molecular weight HA has been reported to down-regulate mitogen RAC signaling and block $\mathrm{S}$ phase progression, whereas low molecular weight HA produced the reverse result [34]. The molecular weight of HA applied in this study was $>1470 \mathrm{kDa}$; thus, it belongs to the high molecular weight category. From the cell cycle population distribution results in the present study, PDMSCs cultured on HA produced a higher percentage of cells in the G0/G1 phase than those cultured on TCS; however, the percentage of cells was similar for HA at $48 \mathrm{~h}$ and TCS at $50 \mathrm{~h}$ for TCS and HA treatments, respectively, because cells proliferated at rate that was more rapid on TCS. In addition, the expression of mesenchymal stem cell markers indicated that HA did not promote cell differentiation.

When PDMSCs had similar cell cycle population distributions among cell cycles, mRNA expression of E2F4 and p130 was higher in HA-based treated cells compared with those cultured on TCS. This result implies that E2F4 and p130 were required at this particular stage

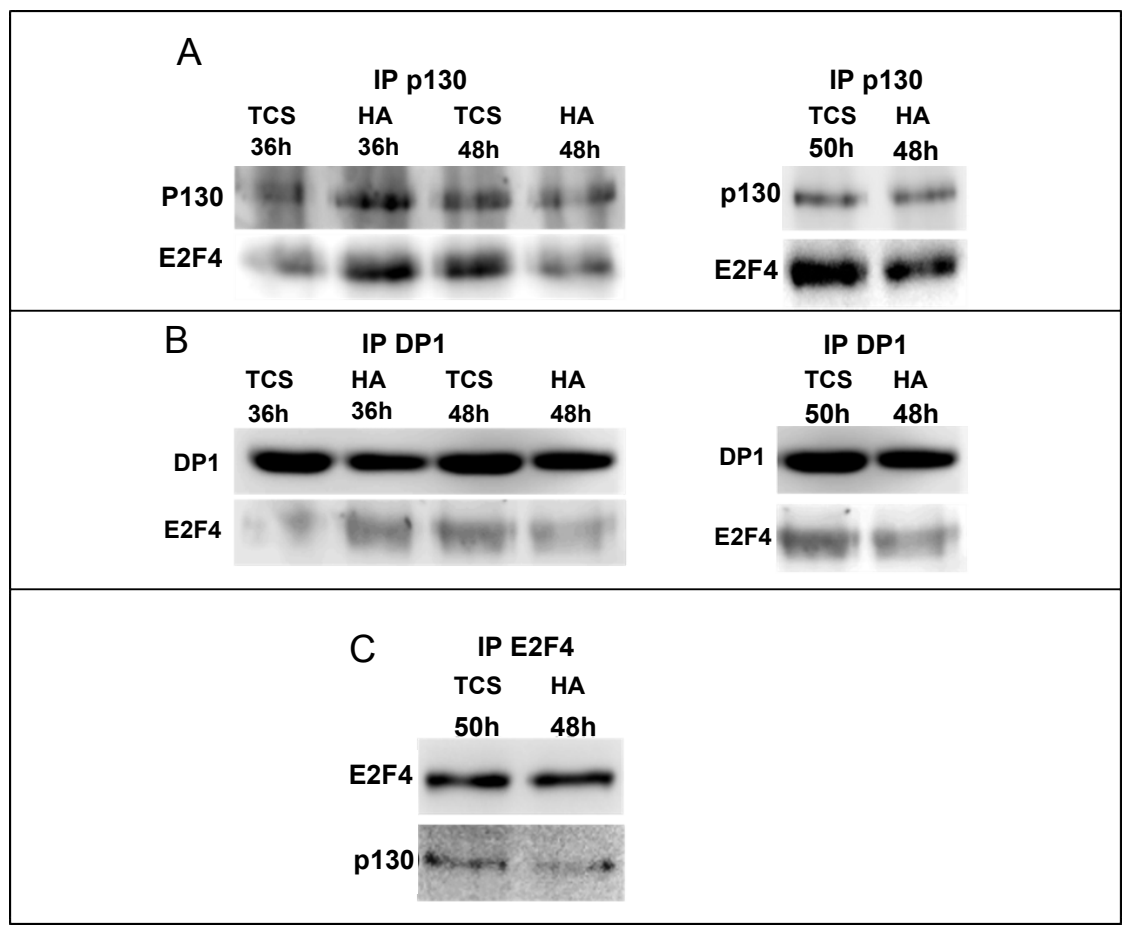

Figure 3: HA-dependent interactions between E2F4 and p130 coupled with DP1. (A) At 36, 48, and 50 h post-cell seeding, PDMSC lysates were harvested, coimmunoprecipitated with anti-p130 antibody, separated using SDS gel, and detected using anti-p130 and anti-E2F4 antibodies in western blots. (B) At 36 , 48, and 50 $\mathrm{h}$ post-cell seeding, PDMSCs lysates were harvested, co-immunoprecipitated with anti-DP1 antibody, separated using SDS gel, and detected using anti-DP1 and antiE2F4 antibodies for detection in western blots. (C) The interaction between p130, E2F4, and DP1 was confirmed through co-immunoprecipitation of the total protein lysates with anti-E2F4 antibody; anti-E2F4 and anti-p130 were then used for detection in western blots. 


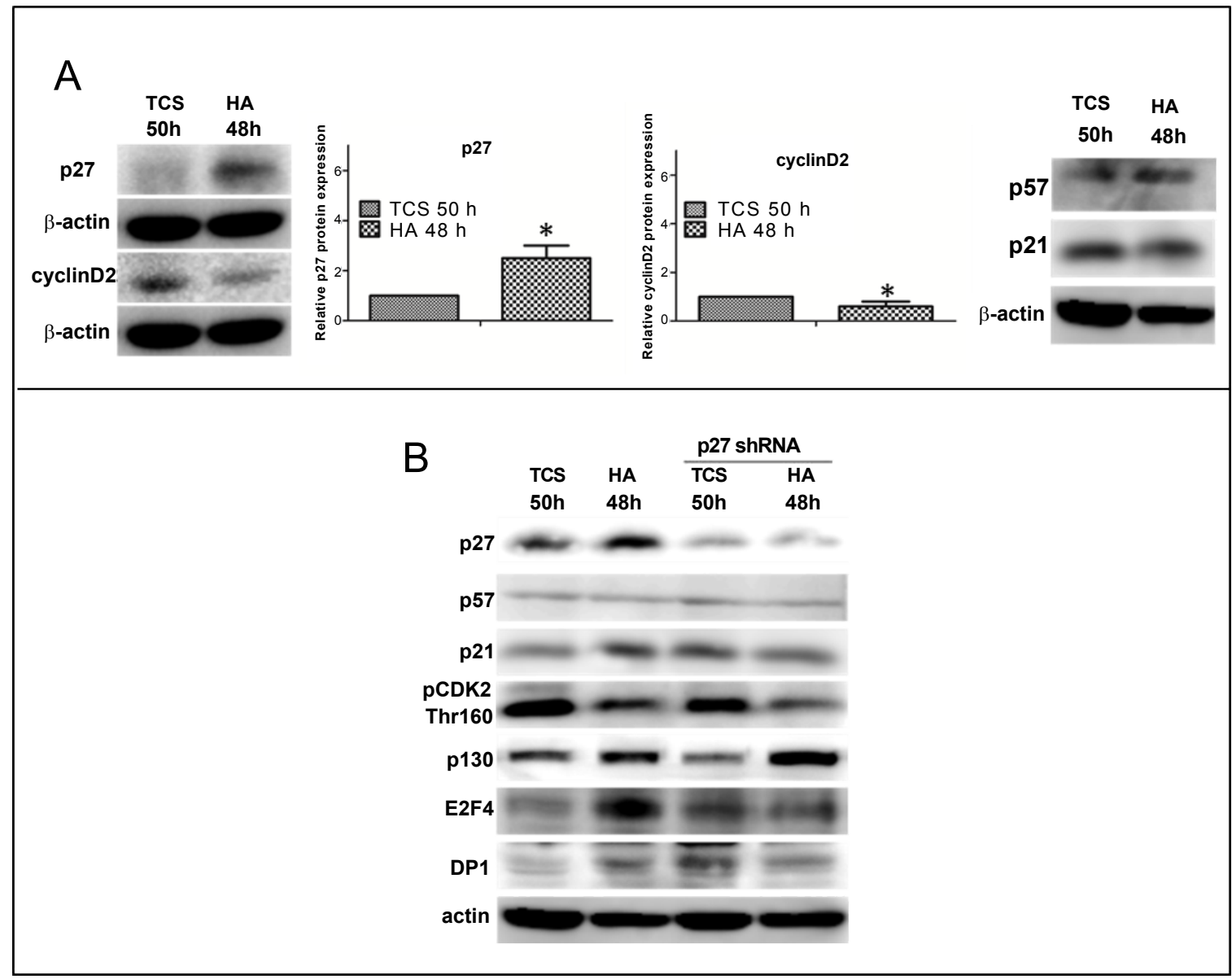

Figure 4: HA prevented transition to the G1/S phase in PDMSCs. (A) The G1/S transition regulators p27 $7^{\mathrm{kip} 1}$, p57 $7^{\mathrm{kip} 1}$, p2 $1^{\mathrm{cip}}$, and cyclin D2 were analyzed using western blotting at $50 \mathrm{~h}$ for TCS-based cells and $48 \mathrm{~h}$ for HA-treated cells. (B) The cells in both groups were treated with p27 shRNA to knock down p27 kip1. Subsequently, protein lysates were harvested and analyzed for expression of p2 $7^{\mathrm{kip} 1}, \mathrm{p} 57^{\mathrm{kip} 1}, \mathrm{p} 21^{\mathrm{cip}}, \mathrm{pCDK} 2, \mathrm{p} 130$, E2F4, and DP1 using western blotting. The data represent the mean \pm SEM from three independent experiments. ${ }^{*} p<0.05,{ }^{* *} p<0.01,{ }^{* * *} p<0.001$ versus TCS.

of growth, which was confirmed with western blot analysis. Previous studies showed that p130 was highly expressed compared with $\mathrm{pRb}$ and p107 during quiescence, and that the E2F4/p130 complex is the major contributor to E2F activity in quiescent cells [35,36]. E2F4 family proteins have been found in quiescent cells [37], which explains the up-regulation of E2F4 in PDMSCs in the presence of HA observed here. Furthermore, the stabilized E2F4/p130 complex is known to repress the transcription of genes targeted by E2F4 to slow down cell proliferation [38]. The results of the present study are consistent with previous observations of a HA-mediated slow-cell cycling phase in PDMSCs [20].

The RB family (pocket proteins) show overlapping functions [39], and the members may compensate for each other and alter their functions at different cell cycle phases [40]. A previous study discovered a complex that consisted of p130, termed the DREAM (DP, Rb-like, E2F, and MuvB) complex, which regulated cell quiescence [41]. Dual-specificity tyrosine (Y)-phosphorylation-regulated kinase 1A (DYRK1A) was reported to enhance quiescence via the DREAM complex [39]. OfConsidering the pocket proteins assessed here, the lack of $\mathrm{Rb}$ (i.e., $\mathrm{pRb}$ ) expression in the HA group indicated that the $\mathrm{pRb} /$ E2F complex was not required in the presence of HA. Furthermore, because p107 expression was not significantly different in the HA and TCS groups, the p130/E2F4 complex was likely dominant in HA- treated PDMSCs. Consistent with this result; G0/G1-arrested cells were regulated through the p130/E2F4 complex in a previous study [42]. Moreover, the function of p130 and E2F4 has been associated not only with quiescence [43] but also cell differentiation [44,45]. The p130/ E2F4 complex is known to interact with $\beta$-catenin to activate the Wnt pathway and promote cell differentiation [45]. The RB family proteins are also important for heart development [46], and p130/E2F4 plays a role in cell proliferation during normal development [41]. However, when $\mathrm{pRb}$ was removed, cells were immortalized [47]; in other words, cells were completely removed from cell cycle checkpoint regulations and proliferated with a lengthened $S$ phase. Taken together, this evidence suggests that RB proteins have a critical role to play in stem cell cycle regulation [48].

CDKs are major cell cycle regulators; cyclin D2 binds to CDK4 and CDK6, which leads to G1 phase progression from G0 [49,50]. Interestingly, cyclin D2 was previously reported to play a role in stem cell fate determination [51,52]. Consistent with this finding, in the present study, expression of cyclin D2 decreased and p27 $7^{\mathrm{kip}}$ increased in HA-treated cells relative to expression in TCS-based cells. The reduction of cyclin D2 may have led to an accumulation of p $27^{\text {kipl }}$ in the nucleus and decreased translocation to the cytoplasm for degradation [53]. CDK2 was reported to bind to cyclin E to promote $S$ phase progression, whereas cyclin $\mathrm{E}$ and $\mathrm{CDK} 2$ were down-regulated 


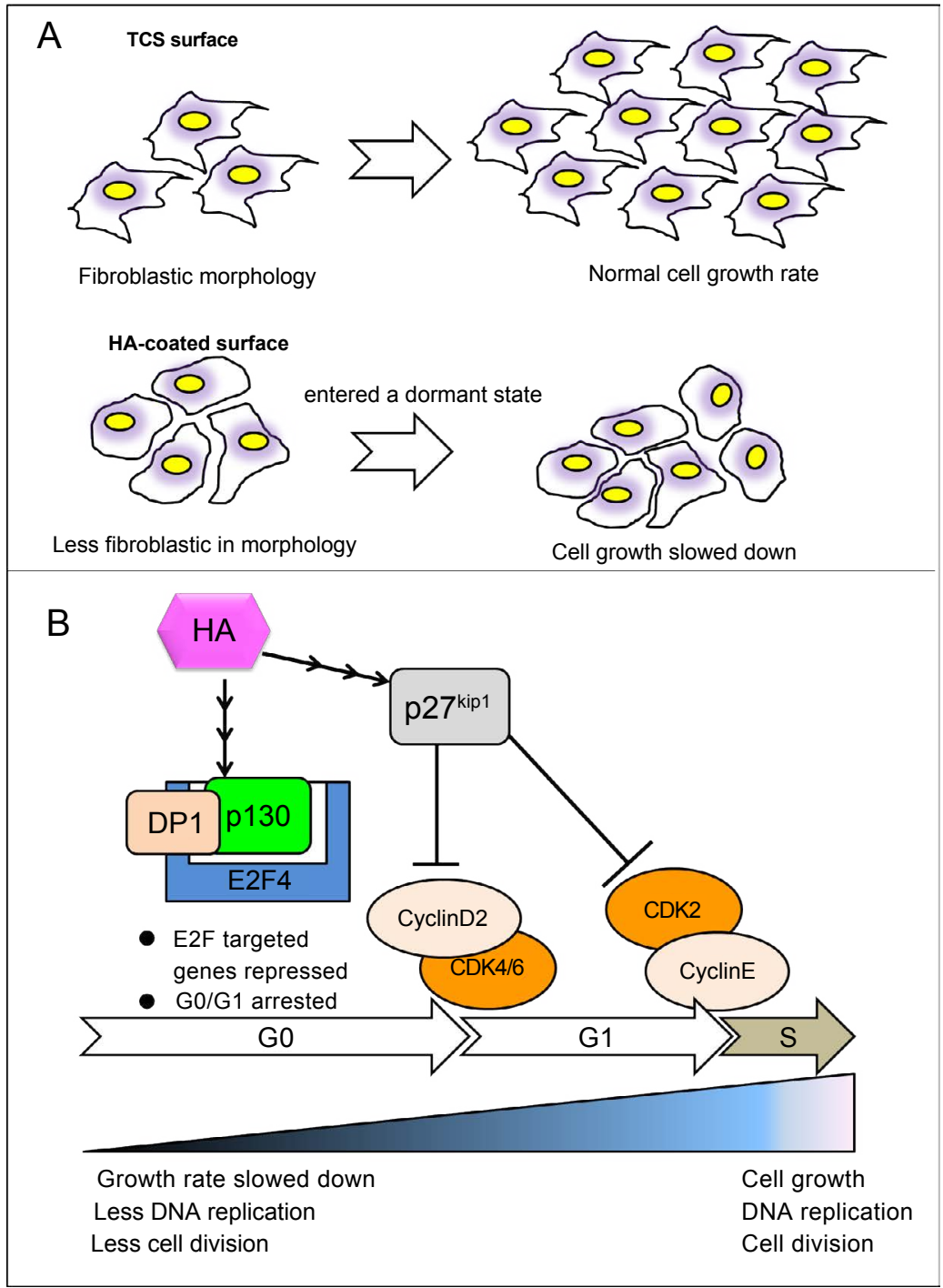

Figure 5: HA influenced the formation of the p130/E2F4/DP1 complex and the up-regulation of the G1/S transition regulator p27 ${ }^{\mathrm{kip}}$. (A) Illustration showing the condition of cell growth of PDMSCs grown on a HA-coated surface. The layer of HA somehow acted as a cushion for the PDMSCs to lie down, which triggered the PDMSCs to enter a dormant state while in vitro. (B) Expression of p130 and E2F4 was higher in HA-treated cells than in TCS-based cells, which suggests that p130/ E2F4 complex formation was up-regulated due to the presence of HA in the surrounding cells.

by cyclin-dependent kinase inhibitors, e.g., p2 $7^{\text {kip1 }}$, p5 $7^{\text {kip2 }}$, and $\mathrm{p} 21^{\text {cip }}$, to prevent $\mathrm{S}$ phase progression from the G1 phase. Additionally, p $27^{\text {kip } 1}$ was found to interact with $\mathrm{p} 21^{\text {cip }}$ to regulate quiescence in hematopoietic stem cells $[54,55]$. However, in the present study, the knockdown of $\mathrm{p} 27^{\mathrm{kip} 1}$ did not lead to up-regulation of pCDK2 (the phosphorylated state of CDK2 ${ }^{\text {Thr160 }}$ ) in HA-based cells, which suggests that PDMSCs were persistently maintained in growth arrest due to the presence of HA. Conversely, the loss of $\mathrm{p} 27^{\mathrm{kip} 1} \mathrm{did}$ not lead to downregulation of pCDK2 in TCS-based cells, which indicates that other cell cycle regulators may have maintained pCDK2 activity to allow TCSbased cell proliferation to persist. In addition, p130 expression may have compensated for the loss of $\mathrm{p} 27^{\mathrm{kip} 1}$ in the HA group to further prolong the cell cycle arrest in G0/G1 [56].

It is likely that the role of HA in the stem cell niche may be to maintain stem cells in their most pristine state, i.e., to allow them to lie dormant and avoid provocative stimuli. Because of the complicated state of the microenvironment, the protective action of HA towards stem cells may be readily disrupted. Prior to the present study, the involvement of HA in p130/E2F4 complex formation in mesenchymal stem cells was unclear. We conclude that p130/E2F4 was dominant in HA-treated PDMSCs, and that HA not only maintained PDMSCs in a slow proliferating state but also regulated their cell cycle through p130/ E2F4 formation.

\section{Acknowledgments}

This research was supported and funded by the National Science Council (NSC99-3111-B-006-002).

\section{Conflict of Interest}

The authors declare that there are no conflicts of interest related to this study.

\section{References}

1. Stanworth SJ, Newland AC (2001) Stem cells: progress in research and edging towards the clinical setting. Clin Med (Lond) 1: 378-382. [PubMed]

2. Evans MJ, Kaufman MH (1981) Establishment in culture of pluripotential cells from mouse embryos. Nature 292: 154-156. [PubMed] 
Citation: Lin MR, Wong TY, Wu CH, Huang LLH (2016) Hyaluronan Elevates Cell Cycle Regulators P130, E2F4, and P27 $7^{\mathrm{kip} 1}$ in Dormant Human Mesenchymal Stem Cells to Regulate Cell Quiescence. J Stem Cell Res Ther 6: 345. doi:10.4172/2157-7633.1000345

Page 8 of 9

3. McGuckin C, Forraz N, Allouard Q, Pettengell R (2004) Umbilical cord blood stem cells can expand hematopoietic and neuroglial progenitors in vitro. Exp Cell Res 295: 350-359. [PubMed]

4. Cheung TH, Rando TA (2013) Molecular regulation of stem cell quiescence. Nature Reviews Molecular Cell Biology 14: 329-340. [PubMed]

5. Bobis S, Jarocha D, Majka M (2006) Mesenchymal stem cells: characteristics and clinical applications. Folia Histochem Cytobiol 44: 215-230. [PubMed]

6. Haylock DN, Nilsson SK (2005) Stem cell regulation by the hematopoietic stem cell niche. Cell Cycle 4: 1353-1355. [PubMed]

7. Kolf CM, Cho E, Tuan RS (2007) Mesenchymal stromal cells. Biology of adult mesenchymal stem cells:regulation of niche, self-renewal and differentiation. Arthritis Res Ther 9: 204. [PubMed]

8. Castellucci M, Kosanke G, Verdenelli F, Huppertz B, Kaufmann P (2000) Villous sprouting: fundamental mechanisms of human placental development. Hum Reprod Update 6: 485-494. [PubMed]

9. Itano N, Kimata K (2000) Mammalian Hyaluronan Synthases. IUBMB Life 254 195-199. [PubMed]

10. Spicer AP, McDonald JA (1998) Characterization and Molecular Evolution of a Vertebrate Hyaluronan Synthase Gene Family. J biol chem 273: 1923-1932. [PubMed]

11. Sayo T, Sugiyama Y, Takahashi Y, Ozawa N, Sakai S, et al. (2002) Hyaluronan Synthase 3 Regulates Hyaluronan Synthesis in Cultured Human Keratinocytes. J Inves Dermatol 118: 43-48. [PubMed]

12. Laurent TC, Fraser JR (1992) Hyaluronan. FASEB J 6: 2397-2404. [PubMed]

13. Solis MA, Chen YH, Wong TY, Bittencourt VZ, Lin YC, et al. (2012) Hyaluronan Regulates Cell Behavior: A Potential Niche Matrix for Stem Cells. Biochem Res Int. [PubMed]

14. Toole BP (2004) Hyaluronan: from extracellular glue to pericellular cue. Nat Rev Cancer 4: 528-539. [PubMed]

15. Fujiwara T, Kawakatsu T, Tayama S, Kobayashi Y, Sugiura N, et al. (2008) Hyaluronan-CD44 pathway regulates orientation of mitotic spindle in normal epithelial cells. Genes Cells 13: 759-770. [PubMed]

16. Slevin M, Krupinski J, Gaffney J, Matou S, West D, et al. (2007) Hyaluronanmediated angiogenesis in vascular disease: uncovering RHAMM and CD44 receptor signaling pathways. Matrix Biol 26: 58-68. [PubMed]

17. Goody MF, Sher RB, Henry CA (2015) Hanging on for the ride: Adhesion to the extracellular matrix mediates cellular responses in skeletal muscle morphogenesis and disease. Dev Biol 401: 75-91. [PubMed]

18. Kurtz A, Oh SJ (2012) Age related changes of the extracellular matrix and stem cell maintenance. Prev Med 54: S50-S56. [PubMed]

19. Chen PY, Huang LL, Hsieh HJ (2007) Hyaluronan preserves the proliferation and differentiation potentials of long-term cultured murine adipose-derived stromal cells. Biochem Biophys Res Commun 360: 1-6. [PubMed]

20. Liu CM, Yu CH, Chang CH, Hsu CC, Huang LLH (2008) Hyaluronan substratum holds mesenchymal stem cells in slow-cycling mode by prolonging $\mathrm{G} 1$ phase. Cell Tissue Res 334: 435-443. [PubMed]

21. Dyson N (1998) The regulation of E2F by pRB-family proteins. Genes Dev 12 2245-2262. [PubMed]

22. Wells J, Boyd KE, Fry CJ, Bartley SM, Farnham PJ (2000) Target Gene Specificity of E2F and Pocket Protein Family Members in Living Cells. Mol Cell Biol 20: 5797-5807. [PubMed]

23. Chong JL, Tsai SY, Sharma N, Opavsky R, Price R, et al. (2009) E2f3a and $\mathrm{E} 2 \mathrm{f} 3 \mathrm{~b}$ contribute to the control of cell proliferation and mouse development. Mol Cell Biol. 29: 414-424. [PubMed]

24. Grana X, Garriga J, Mayol X (1998) Role of the retinoblastoma protein family, pRB, p107 and p130 in the negative control of cell growth. Oncogene 17: 33653383. [PubMed]

25. Burke JR, Deshong AJ, Pelton JG, Rubin SM (2010) Phosphorylation-induced conformational changes in the retinoblastoma protein inhibit E2F transactivation domain binding. J Biol Chem 285: 16286-16293. [PubMed]

26. Leibundgut K, Schmitz NM, Hirt A (2005) Catalytic activities of G1 cyclindependent kinases and phosphorylation of retinoblastoma protein in mobilized peripheral blood CD34+ hematopoietic progenitor cells. Stem Cells 23: 1002 1011. [PubMed]

27. Dimova DK, Dyson NJ (2005) The E2F transcriptional network: old acquaintances with new faces. Oncogene 24: 2810-2826. [PubMed]

28. Johnson D, Schneider-Broussard R (1998) Role of E2F in cell cycle control and cancer. Front Biosci 3: 447-458. [PubMed]

29. Scimè A, Li L, Ciavarra G, Whyte $P(2008)$ Cyclin D1/cdk4 can interact with E2F4/DP1 and disrupts its DNA-binding capacity. J Cell Physiol 214: 568-581. [PubMed]

30. Villanueva J, Yung Y, Walker JL, Assoian RK (2007) ERK Activity and G1 Phase Progression: Identifying Dispensable Versus Essential Activities and Primary Versus Secondary Targets. Mol Biol Cell 18: 1457-1463. [PubMed]

31. The I, Ruijtenberg S, Bouchet BP, Cristobal A, Prinsen MBW, et al. (2015) Rb and FZR1/Cdh1 determine CDK4/6-cyclin D requirement in C. elegans and human cancer cells. Nat Commun. [PubMed]

32. Neganova I, Lako M (2008) G1 to S phase cell cycle transition in somatic and embryonic stem cells. J Anat 213: 30-44. [PubMed]

33. Julian LM, Blais A (2015) Transcriptional control of stem cell fate by E2Fs and pocket proteins. Front Genet 6. [PubMed]

34. Kothapalli D, Flowers J, Xu T, Pure' E, Assoian RK (2008) Differential Activation of ERK and Rac Mediates the Proliferative and Anti-proliferative Effects of Hyaluronan and CD44. J Biol Chem 283: 31823-31829. [PubMed]

35. Rempel RE, Saenz-Robles MT, Storms R, Morham S, Ishida KS, et al. (2000) Loss of E2F4 Activity Leads to Abnormal Development of Multiple Cellular Lineages. Mol Cell 2000 6: 293-306. [PubMed]

36. Henley SA, Dick FA (2012) The retinoblastoma family of proteins and their regulatory functions in the mammalian cell division cycle. Cell Div 7: 10 [PubMed]

37. Gaubatz S, Lees JA, Lindeman GJ, Livingston DM (2001) E2F4 is exported from the nucleus in a CRM1-dependent manner. Mol Cell Biol 21: 1384-1392. [PubMed]

38. Popov B, Chang LS, Serikov V (2005) Cell cycle-related transformation of the E2F4-p130 repressor complex. Biochem Biophys Res Comm 336: 762-769 [PubMed]

39. Litovchick L, Florens LA, Swanson SK, Washburn MP, DeCaprio JA (2011) DYRK1A protein kinase promotes quiescence and senescence through DREAM complex assembly. Genes Dev 25: 801-813. [PubMed]

40. Balciunaite E, Spektor A, Lents NH, Cam H, Riele HT, et al. (2005) Pocket protein complexes are recruited to distinct targets in quiescent and proliferating cells. Mol Cell Biol 25: 8166-8178. [PubMed]

41. Litovchick L, Sadasivam S, Florens L, Zhu X, Swanson SK, et al. (2007) Evolutionarily Conserved Multisubunit RBL2/p130 and E2F4 Protein Complex Represses Human Cell Cycle-Dependent Genes in Quiescence. Mol Cell 26 539-551. [PubMed]

42. Kurimchaka A, Graña X (2015) PP2A: more than a reset switch to activate pRB proteins during the cell cycle and in response to signaling cues. Cell Cycle 14 18-30. [PubMed]

43. Lee BK, Bhinge AA, lyer VR (2011) Wide-ranging functions of E2F4 in transcriptional activation and repression revealed by genome-wide analysis. Nucleic Acids Res 2011: 1-16. [PubMed]

44. Petrov N, Zhidkova O, Zenin V, Rozanov I, Popov B (2011) The cell cycle regulator $\mathrm{p} 130$ and beta-catenin form a complex in mesenchymal stem cells Tsitologiia 53: 107-115. [PubMed]

45. Popov B, Petrov N (2014) pRb-E2F signaling in life of mesenchymal stem cells Cell cycle, cell fate, and cell differentiation. Genes \& Diseases 1: 174-187.

46. Park DS, Tompkins RO, Liu F, Zhang J, Phoon CKL, et al. (2013) Pocket proteins critically regulate cell cycle exit of the trabecular myocardium and the ventricular conduction system, Biol Open 2: 968-978. [PubMed]

47. Classon M, Salama S, Gorka C, Mulloy R, Braun P, et al. (2000) Combinatorial roles for pRB, p107, and p130 in E2F-mediated cell cycle control. PNAS 97 10820-10825. [PubMed]

48. Kareta M, Gorges L, Hafeez S, Benayoun B, Marro S, et al. (2015) Inhibition of pluripotency networks by the $\mathrm{Rb}$ tumor suppressor restricts reprogramming and tumorigenesis. Cell Stem Cell 16: 39-50. [PubMed] 
Citation: Lin MR, Wong TY, Wu CH, Huang LLH (2016) Hyaluronan Elevates Cell Cycle Regulators P130, E2F4, and P27 $7^{\text {kip }}$ in Dormant Human Mesenchymal Stem Cells to Regulate Cell Quiescence. J Stem Cell Res Ther 6: 345. doi:10.4172/2157-7633.1000345

49. Hall M, Peters G (1996) Genetic alterations of cyclins, cyclin-dependent kinases, and Cdk inhibitors in human cancer. Adv Cancer Res 68: 67-108. [PubMed]

50. Wolowiec D (1994) Cyclins and proliferative pathology. Acta Haematol Pol 25: 195-203. [PubMed]

51. Calegari F (2012) CyclinD2 at the edge: splitting up cell fate. EMBO J 31: 1850 1852. [PubMed]

52. Tsunekawa Y, Kikkawa T, Osumi N (2014) Asymmetric inheritance of Cyclin D2 maintains proliferative neural stem/progenitor cells: A critical event in brain development and evolution. Dev Growth Differ 56: 349-357. [PubMed]
53. Susaki E, Nakayama K, Nakayama KI (2007) Cyclin D2 Translocates p27 out of the Nucleus and Promotes Its Degradation at the G0-G1 Transition. Mol Cell Biol 27: 4626-4640. [PubMed]

54. Wang SH, Lin SY (2013) Tumor dormancy potential therapeutic target in tumo recurrence and metastasis prevention. Exp Hematol Oncol 2: 29.

55. Zou P, Yoshihara H, Hosokawa K, Tai I, Shinmyozu K, et al. (2011) p57(Kip2) and p27(Kip1) cooperate to maintain hematopoietic stem cell quiescence through interactions with Hsc70. Cell Stem Cell 9: 247-261. [PubMed]

56. Soeiro I, Mohamedali A, Romanska HM, Lea NC, Child ES, et al. (2006) p27Kip1 and p130 Cooperate To Regulate Hematopoietic Cell Proliferation In Vivo. Mol Cell Biol 26: 6170-6184. [PubMed] 